\title{
Diosmin suppresses the proinflammatory mediators in lipopolysaccharide-induced RAW264.7 macrophages via NF-KB and MAPKs signal pathways
}

\author{
Mehmet Berköz \\ Department of Biochemistry, Faculty of Pharmacy, Van Yuzuncu Yil University, 65080, Van, Turkey
}

\begin{abstract}
Diosmin is an unsaturated flavonoid glycoside, presents in citrus fruits. The aim of this study is to investigate the molecular mechanism of diosmin with respect to the NF- $\mathrm{KB}$ and MAPKs signaling pathways. Firstly, 10, 20, 30, 40 and $50 \mu \mathrm{M}$ diosmin were treated to lipopolysaccharide (LPS)-stimulated RAW264.7 macrophages. The anti-inflammatory effects of diosmin was displayed via measuring prostaglandin $\mathrm{E}_{2}\left(\mathrm{PGE}_{2}\right)$, nitric oxide $(\mathrm{NO})$, interleukines (IL-6, IL-12), tumor necrosis factor $\alpha$ (TNF- $\alpha$ ) production, cyclooxygenase-2 (COX-2), inducible nitric oxide synthase (iNOS), IL-6, IL-12, TNF- $\alpha$ mRNA levels, and phosphorylation levels of nuclear factor of kappa light polypeptide gene enhancer in B-cells inhibitor alpha (IкB- $\alpha$ ) and mitogen-activated protein kinases (MAPKs); JNK, ERK, and p38 in LPS induced RAW264.7 macrophages. Our study showed that especially high concentrations of diosmin decreased NO, $\mathrm{PGE}_{2}, \mathrm{IL}-6, \mathrm{IL}-12$, TNF- $\alpha$ production and mRNA levels of these mediators $(p<0.05)$. The expression of phosphorylated-JNK was significantly suppressed by diosmin at 40 and $50 \mu \mathrm{M}$ concentrations. Furthermore, diosmin significantly inhibited the expression of phosphorylated-ERK, p38, and p-IKB- $\alpha$ in a dose-dependent manner. Our results suggest that diosmin is a potent anti-inflammatory agent and has potential for development into a therapeutic agent for inflammation-associated disorders.
\end{abstract}

Key words: Diosmin - Inflammation - Raw264.7 - Lipopolysaccharide - MAPKs - NF-кB

\section{Introduction}

Inflammation is a kind of innate immunity that provides a defense against pathogens, damaged cells, and other dangerous molecules. Inflammatory cells, such as macrophages and neutrophils, let leukocytes and plasma components come to sites where infection or injury has occurred during inflammation to eliminate dangers (Nowarski et al. 2013; Lee et al. 2016). Although inflammation is important to the immune system, excessive activity of inflammatory cells can cause cancer, rheumatoid arthritis, multiple sclerosis, chronic asthma, psoriasis, and other diseases (Gautam and Jachak 2009; Nowarski et al. 2013; Ren et al. 2016). To treat those inflammation-driven diseases, inflammatory responses should be controlled.

Correspondence to: Mehmet Berköz, Department of Biochemistry, Faculty of Pharmacy, Van Yuzuncu Yil University, Zeve Campus, 65080, Tuşba, Van, Turkey

E-mail: mehmet_berkoz@yahoo.com
Macrophages activated by lipopolysaccharide (LPS) can enhance the production of inflammatory mediators and cytokines, including nitric oxide (NO), inducible nitric oxide synthase (iNOS), cyclooxygenase-2 (COX-2), interleukin (IL)-6, IL-12, and tumor necrosis factor- $\alpha$ (TNF- $\alpha$ ) (Yun et al. 2014). The production of proinflammatory markers is closely linked to the activation of nuclear factorkappa $\mathrm{B}(\mathrm{NF}-\kappa \mathrm{B})$ and mitogen-activated protein kinases (MAPKs) in macrophages (Jung et al. 2007). NF- $\kappa B$, a primary transcription factor, regulates the expression of various cellular gene-encoding factors for inflammatory responses. The MAPK signaling pathways, which include extracellular signal-regulated kinase (ERK), c-Jun N-terminal kinase (JNK), and p38, are known to induce COX-2 and iNOS expression in LPS-stimulated macrophage (Song et al. 2016). Moreover, Guha and Mackman (2001) have reported that MAPKs play a critical role in the activation of the NF- $\kappa B$ signaling pathway. Therefore, compounds that regulate both the NF- $\kappa B$ and MAPKs pathways have the potential to prevent inflammatory diseases (Song et al. 2016). 
Diosmin (3',5,7-trihydroxy-4'-methoxyflavone 7-rutinoside) is an unsaturated flavonoid glycoside, presents in citrus fruits (Melin et al. 1996). It is an oral phlebotropic drug used in the treatment of venous disease, that is, chronic venous insufficiently (CVI) and hemorrhoidal diseases (Cesarone et al. 2005). It might have potential in the treatment of neurodegenerative disease such as Alzheimer's diseases, and its anti-inflammatory and antiapoptotic activities have been demonstrated in neuronal cells (Dholakiya and Benzeroual 2011). Also it has antioxidant antihyperglycemic, and antimutagenic properties (Rajasekar et al. 2016). In rat models, Ahmed and colleagues (2016) showed a nephroprotective role for diosmin against alloxan-induced nephropathy, while Tahir et al. (2013) highlighted its beneficial effect against alcoholic liver injury. Moreover, diosmin could successfully improve cardiac function and exert antihyperlipidemic effects against isoproterenol-induced myocardial injury in rats (Queenthy and John 2013). However, there is no detailed research regarding the anti-inflammatory mechanism of diosmin. In this study, we aimed to explore the molecular mechanism of diosmin with respect to the NF- $\mathrm{BB}$ and MAPKs signaling pathways.

\section{Materials and Methods}

\section{Materials}

RAW264.7 cells, a transformed macrophage cell line derived from the BALB/c mouse, were purchased from American Type Cell Culture (ATCC) (Rockville, MD, USA). Primary antibodies against $\beta$-actin, JNK, ERK, p38, phosphorylated nuclear factor of kappa light polypeptide gene enhancer in B-cells inhibitor alpha (p-IкB- $\alpha$ ), phosphorylated-JNK, phosphorylated-ERK, and phosphorylated-p38 were purchased from Santa Cruz Biotechnology (Santa Cruz, CA, USA). A protein assay kit was obtained from Pierce BCA Protein Assay Kit (Thermo Fisher Scientific, Massachusetts, USA). The enzyme-linked immunosorbent assay (ELISA) kits used to quantitate the levels of $\mathrm{PGE}_{2}$ were purchased from Lifespan Biosciences (Seattle, WA, USA). Diosmin, Dulbecco's modified Eagle's medium (DMEM), fetal bovine serum (FBS), penicillin/streptomycin, L-glutamine, 3-(4,5-dimethylthiazol2-yl)-2,5-diphenyltetrazolium bromide (MTT), L-NAME, LPS, and Griess reagent were purchased from Sigma-Aldrich Co. (St. Louis, MO, USA). Specific PCR primers for genes $I L$ 6, IL-12, TNF- $\alpha$, iNOS, COX-2, and $\beta$-actin were synthesized from PRZ BioTECH (Bilkent, Ankara, Turkey). All solvents used were of HPLC grade.

\section{Cell culture}

The RAW 264.7 murine macrophage cell line was purchased from ATCC (ATCC number TIB-71). The cells were grown in DMEM supplemented with $10 \%$ foetal bovine serum (FBS) and $1 \%$ antibiotic-antimycotic solution $(100 \mathrm{U} / \mathrm{ml}$ penicillin G sodium, $100 \mu \mathrm{g} / \mathrm{ml}$ streptomycin sulphate, and $0.25 \mu \mathrm{g} / \mathrm{ml}$ amphotericin B) to a subconfluent density. The cells were cultured at $37^{\circ} \mathrm{C}$ in a humidified incubator in an atmosphere of $5 \% \mathrm{CO}_{2}$ (Meng et al. 2013).

\section{Cell viability assay}

MTT assay was performed to determine the cytotoxicity and cell viability of diosmin on RAW 264.7 macrophages. The $100 \mu$ l of RAW 264.7 macrophages was seeded in triplicate into 96-well plates $\left(2 \times 10^{4}\right.$ cells/well) and incubated for $24 \mathrm{~h}$ (Lee et al. 2013). The macrophages were treated with various gradient concentration of diosmin with serial dilutions at 2.5, 5, 7.5, $10,20,30,40,50,100,150,200,250$, and $500 \mu \mathrm{M}$ and then incubated for $24 \mathrm{~h}$. Briefly, thereafter, $10 \mu \mathrm{l}$ of MTT solution $(10 \mathrm{mg} / \mathrm{ml})$ in phosphate-buffered solution ( $\mathrm{pH} 7.4)$ was added to each well and then followed by incubation for another $3 \mathrm{~h}$. The medium was removed and the purple formazan crystals formed were dissolved by adding $100 \mu \mathrm{l}$ dimethyl sulfoxide (DMSO). The plate was swirled gently to mix well and kept in dark condition at room temperature for $30 \mathrm{~min}$. The absorbance was determined by using Microplate Reader 680 XR (Bio-Rad Laboratories, California, USA) at $570 \mathrm{~nm}$ wavelength.

The percentage of surviving cells was calculated using the following formula: Cell viability $(\%)=$ (mean absorbance in test wells/mean absorbance in control wells $) \times 100$ (Baek et al. 2015).

\section{NO production assay}

RAW264.7 macrophages were plated in a 96-well plate $\left(2 \times 10^{4}\right.$ cells/well) overnight, followed by the addition of $1 \mu \mathrm{g} / \mathrm{ml} \mathrm{LPS}$ for $24 \mathrm{~h}$ in the presence or absence of different concentration of diosmin with increasing concentration at 10, 20, 30,40, and $50 \mu \mathrm{M}$. To analyze NO production, $100 \mu \mathrm{l}$ of supernatant was incubated with equal volume of Griess solution $(0.1 \%$ $\mathrm{N}$-1-naphthylethylendiamide-dihydrochloride (NED), 1\% sulphanilamide, and $2.5 \%$ phosphoric acid) in room temperature for $10 \mathrm{~min}$ in dark condition and absorbance was then read at $540 \mathrm{~nm}$. Since NO content was reflected by the amount of nitrite, a calibration curve was generated using sodium nitrite. The amount of nitrite in the supernatants was calculated based on the calibration curve. The percentage inhibition of NO production is evaluated using the formula 1-[(nitrite amount of fraction-treated)/(nitrite amount of vehicle)]\} $\times 100$ (Baek et al. 2016).

\section{Determination of $P G E_{2}$ levels}

To assess whether diosmin could inhibit the production of $\mathrm{PGE}_{2}$ in LPS-induced RAW 264.7 macrophages, the cells 
were pretreated with diosmin for $1 \mathrm{~h}$ before incubation with LPS $(1 \mu \mathrm{g} / \mathrm{ml})$ for $24 \mathrm{~h}$. After incubation for $24 \mathrm{~h}$, the cell culture medium was harvested, and the production of $\mathrm{PGE}_{2}$ was measured using an ELISA. The levels of $\mathrm{PGE}_{2}$ were determined using $\mathrm{PGE}_{2}$ ELISA kit (Lifespan Biosciences, Seattle, WA, USA) according to the manufacturer's instruction (Yi et al. 2016). Briefly, cells were grown at a density of $2 \times 10^{4}$ cells/ well and treated with different concentrations of diosmin for $1 \mathrm{~h}$ before incubation with LPS $(1 \mu \mathrm{g} / \mathrm{ml})$ for $24 \mathrm{~h}$. Following incubation, $50 \mu \mathrm{l}$ of medium was added to wells of antibody coated 96-well plates. Then, $50 \mu$ of mouse anti-PGE 2 and 50 $\mu \mathrm{l}$ of diluted conjugate were added and incubated for $1 \mathrm{~h}$ at room temperature on well plate shaker. The reaction mixture was removed from each well and washed four times with washing buffer. Subsequently, $150 \mu \mathrm{l}$ of 3,3,5,5'-tetramethylbenzidine (TMB) enzyme substrate were added into each well and incubated for $30 \mathrm{~min}$ at room temperature (RT) on microplate shaker. After adding $100 \mu$ l of stop solution, the OD was measured at $450 \mathrm{~nm}$ using Microplate Reader 680 XR (Bio-Rad Laboratories, California, USA). The data were expressed as the means of at least three independent experiments. Each value was expressed as the mean \pm SD of triplicate experiments.

\section{Cytokine determination}

The levels of IL-6, IL-12, and TNF- $a$ were determined using Lifespan Biosciences ELISA kits (Seattle, WA, USA) according to the manufacturer's instructions (Rajapakse et al. 2008). Briefly, the cells were grown at a density of $2 \times 10^{4}$ cells/well and treated with different concentrations of diosmin $(10-50 \mu \mathrm{M})$ for $1 \mathrm{~h}$ before incubation with LPS $(1 \mu \mathrm{g} / \mathrm{ml})$ for the indicated times. Following incubation, 50 $\mu \mathrm{l}$ of medium was added to wells of antibody-coated 96well plates. Then, $50 \mu \mathrm{l}$ of biotinylated antibody reagent was added and incubated for $3 \mathrm{~h}$ at RT. The reaction mixture was removed from each well and washed four times with washing buffer. Subsequently, $100 \mu \mathrm{l}$ of streptavidin conjugated to horseradish peroxidase was added and incubated for $30 \mathrm{~min}$ at RT. After the same washing step as above, $100 \mu \mathrm{l}$ of TMB substrate solution was added and incubated for $30 \mathrm{~min}$ at room temperature. After adding $50 \mu \mathrm{l}$ of stop solution, the optical density was measured at $450 \mathrm{~nm}$ using Microplate Reader 680 XR (Bio-Rad Laboratories, California, USA).

\section{Measurement of mRNA expression levels}

RAW264.7 cells $\left(5 \times 10^{4}\right.$ cells/well $)$ were seeded in 24 -well plates. After reaching approximately $70 \%$ confluence, each well was treated with various concentrations of diosmin together with LPS $(1 \mu \mathrm{g} / \mathrm{ml})$. After $4 \mathrm{~h}$ incubation, total RNA was isolated using TRIzol reagent (Invitrogen,
Carlsbad, CA, USA). Real-time RT-PCR was performed with a Roche LightCycler 480 II device using SYBR Green PCR master mix (Invitrogen, Carlsbad, CA, USA). PCR amplification was carried out using the following primers: IL-6, forward (5' ${ }^{\prime}$ CCT CTG GTC TTC TGG AGT ACC3') and reverse (5'-ACT CCT TCT GTG ACT CCA GC-3) (Zhu et al. 2015); $I L-12$, forward (5'-TGC TCA TGG CTG GTG CAA AG-3') and reverse (5'-TGG ACT TCG GTA GAT GTC TTC-3') (Saito et al. 2006); TNF- $\alpha$, forward (5'-ATG AGC ACA GAA AGC ATG A-3') and reverse (5'-AGT AGA CAG AAG AGC GTG GT-3') (Zhu et al. 2015); iNOS, forward (5'-CCC TTC CGA AGT TTC TGG CAG CAG C-3') and reverse (5'-GGC TGT CAG AGC CTC GTG GCT TTG G-3'); COX-2, forward (5'-GTC TGA TGA TGT ATG CCA CAA TCT G-3') and reverse (5'- GAT GCC AGT GAT AGA GGG TGT TAA A-3') and $\beta$-actin (as a mouse housekeeping gene), forward (5'-AGG TCA TCA CTA TTG GCA AC-3') and reverse (5'-ACT CAT CGT ACT CCT GCT TG-3') (Berkoz and Allahverdiyev 2017). All mRNA expression was normalized using $\beta$-actin. Relative expression levels were calculated using the comparative method.

\section{Western blotting}

RAW264.7 macrophages were cultured in DMEM containing $10 \%(\mathrm{v} / \mathrm{v})$ FBS at $70-80 \%$ confluency. The cells were incubated with $1 \mu \mathrm{g} / \mathrm{ml}$ LPS for $24 \mathrm{~h}$. The cells were then lysed with $1 \times$ cell lysis buffer (Cell Signaling Technology), and protein concentration was measured using a Pierce BCA Protein Assay Kit (Thermo Fisher Scientific). Equal quantities of total protein were loaded onto a $10 \%$ SDS polyacrylamide gel (Bio-Rad Laboratories) for separation. The separated proteins were transferred to Immobilon P membranes (Millipore, Billerica, MA, USA). Nonspecific proteins were blocked with $5 \%$ fat-free milk for $1 \mathrm{~h}$, before the primary antibody was treated at $4^{\circ} \mathrm{C}$ overnight. Protein bands were detected with a chemiluminescence detection kit (GE Healthcare, NJ, USA) after hybridization with an HRP-conjugated secondary antibody (Cell Signaling Technology, Massachusetts, USA). The $\mathrm{p}-\mathrm{I} \kappa \mathrm{B}-\alpha$ protein level was expressed as a relative value to that of $\beta$-actin. $p$-JNK, $p$-ERK, and p-p38 levels were expressed as a relative value to that of JNK, ERK, and p38, respectively. Relative protein levels were quantified by using ImageJ software (National Institutes of Health, Bethesda, MD, USA).

\section{Statistical analysis}

Data are expressed as means \pm standard deviation (SD) of three replicate determinations. Statistical analysis was performed using the unpaired Student's $t$-test or one-way analysis of variance (ANOVA) followed by Tukey post hoc 
test for multiple comparison. The $p$ value of less than 0.05 was considered as a significant difference. Statistical analysis was conducted using SPSS statistics software (version 15.0, SPSS Inc, Chicago, IL, USA).

\section{Results}

We first investigated the cytotoxicity of diosmin to determine the applicable treatment concentration range. MTT reduction assay was used to access the cytotoxicity effect of diosmin at concentration ranging from the lowest to highest $(2.5-500 \mu \mathrm{M})$ on RAW 264.7 macrophages. The cytotoxicity potential of diosmin on macrophages was presented in Figure 1 . A decrease in cell viability by more than $15 \%$ when compared to control cells was considered to be cytotoxic as determined by MTT assay. The results showed that increasing concentrations of diosmin have caused reduction of cell viability. However, diosmin did not exhibit any toxicity to macrophages at concentrations ranging from 10 to $50 \mu \mathrm{M}$. According to the cytotoxicity investigations, the concentrations at $10,20,30,40$, and $50 \mu \mathrm{M}$ were chosen for further anti-inflammatory experiments.

We measured $\mathrm{NO}$ and $\mathrm{PGE}_{2}$ production in LPS-induced RAW264.7 macrophages for determining the possible antiinflammatory effects of diosmin (Fig. 2). The level of NO was markedly increased after treatment with LPS for $24 \mathrm{~h}$; however, diosmin significantly suppressed the release of NO compared with the control exposed to LPS only $(p<0.001)$. Treatment with diosmin at concentration of $40 \mu \mathrm{M}$ decreased NO production by approximately $36 \%$, indicating that this concentration of diosmin possesses highest inhibition of NO production in RAW264.7 $(p<0.05)$. However, 10 and $20 \mu \mathrm{M}$ diosmin showed no statistically significant effect on NO generation compared to control group treated with LPS only $(p>0.05)$ (Fig. 2A).
The production of $\mathrm{PGE}_{2}$ was significantly increased after treatment with LPS for $24 \mathrm{~h}$; however, diosmin significantly suppressed the production of $\mathrm{PGE}_{2}$ compared with the control exposed to LPS only $(p<0.001)$. Of particular note, treatment with diosmin at concentration of $50 \mu \mathrm{M}$ decreased $\mathrm{PGE}_{2}$ production by approximately $33 \%$, indicating that this concentration of diosmin possesses highest inhibition of $\mathrm{PGE}_{2}$ production in RAW264.7 $(p<0.05)$. However, 10 and $20 \mu \mathrm{M}$ diosmin showed no statistically significant effect on $\mathrm{PGE}_{2}$ generation compared to control group treated with LPS only ( $p>0.05$ ) (Fig. 2B).

The effect of diosmin on the expression of cytokines, including IL-6, IL-12, and TNF- $\alpha$, was investigated using LPS-induced RAW264.7 cells (Fig. 3). As shown in Figure 3, very low levels of cytokines were observed in LPS-untreated RAW264.7 cells, whereas macrophages treated with LPS alone for $24 \mathrm{~h}$ significantly $(p<0.001)$ showed an enhanced release of IL-6, IL-12, and TNF- $\alpha$. Diosmin treatment significantly suppressed IL-6, IL-12, and TNF- $\alpha$ production at all concentrations $(p<0.05)$. Diosmin at $40 \mu \mathrm{M}$ concentration exhibited the highest inhibitory effect of IL-6 $(p<0.05)$ (Fig. $3 \mathrm{~A})$. Moreover, diosmin at $50 \mu \mathrm{M}$ concentration showed highest inhibitory effect of IL-12 $(p<0.001)$ (Fig. 3B). The release of TNF- $\alpha$ was significantly decreased by treatment with diosmin in a dose-dependent manner $(p<0.05)$. Diosmin at $50 \mu \mathrm{M}$ concentration exhibited highest inhibitory effect of TNF- $\alpha(p<0.001)$ (Fig. 3C).

RT-PCR was performed to determine whether the inhibitory effects of diosmin on mRNA expression of $i N O S$, COX-2, IL-6, IL-12, and TNF- $\alpha$ (Fig. 4). As shown in Figure $4 \mathrm{~A}$, diosmin at concentrations of 40 and $50 \mu \mathrm{M}$ significantly $(p<0.05)$ reduced the expression of $i N O S$ compared to control group treated with LPS only. Especially, $40 \mu \mathrm{M}$ diosmin inhibited the expression of $i N O S$ by more than $19.5 \%$. As shown in Figure 4B, diosmin at concentrations of 30, 40 and $50 \mu \mathrm{M}$ significantly $(p<0.05)$ reduced the expression

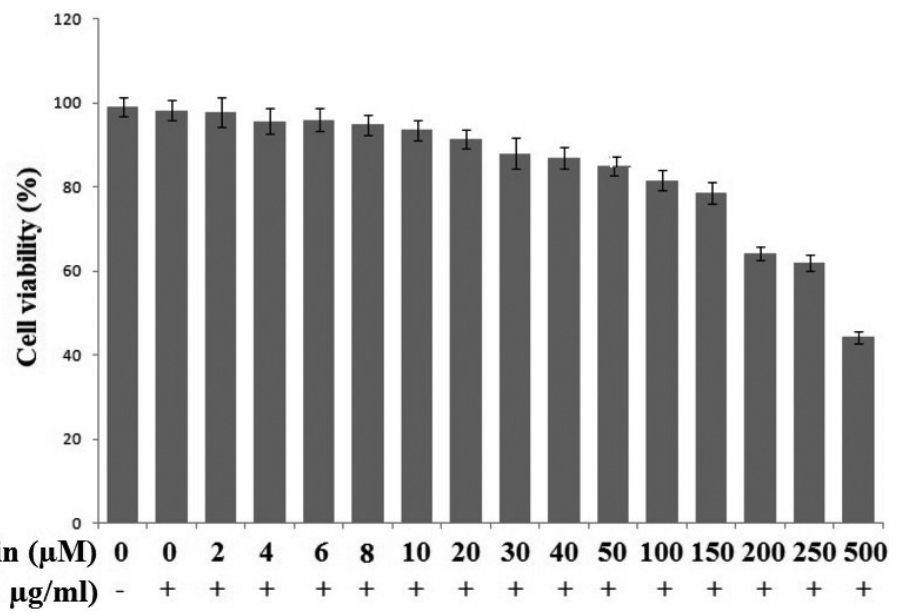

Figure 1. Effect of diosmin on the cell viability of RAW264.7 cells. Cells were plated in 96 well plate at density of $2 \times 10^{4}$ cells $/$ well. The cells were pretreated with various concentrations of samples for $24 \mathrm{~h}$ and cytotoxicity was determined by MTT assay. 
A

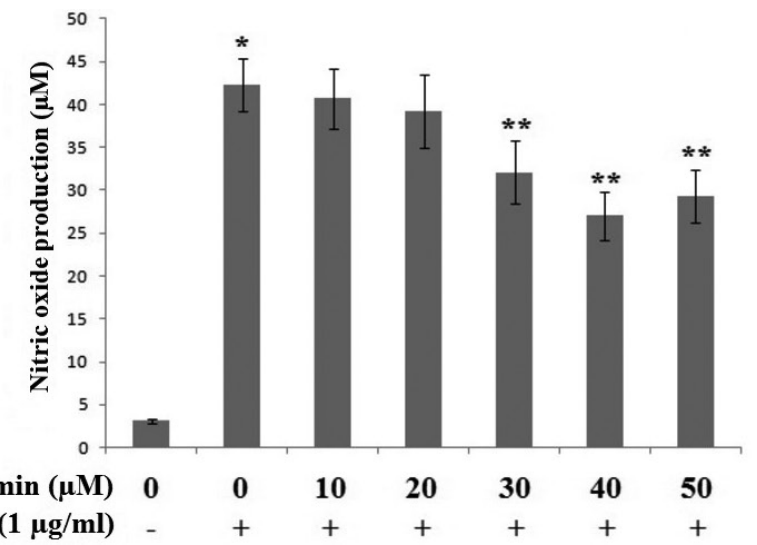

B

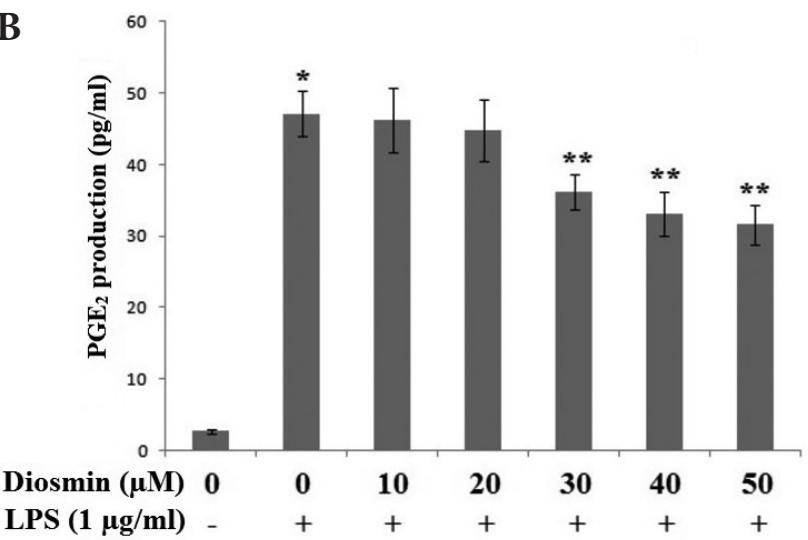

Figure 2. Inhibitory effects of diosmin on $\mathrm{NO}(\mathbf{A})$ and $\mathrm{PGE}_{2}$ (B) production in LPS-induced RAW264.7 macrophages. RAW264.7 macrophages were incubated for $24 \mathrm{~h}$, and exposed to diosmin together with LPS $(1 \mu \mathrm{g} / \mathrm{ml})$ for $24 \mathrm{~h}$. Data represent the means \pm SD of three independent experiments. ${ }^{*} p<0.001$ in comparison to untreated controls; significant difference was determined using unpaired Student's $t$-test; ${ }^{* *} p<0.05$ in comparison to cells treated with LPS alone. (One-way ANOVA followed by Tukey's test for multiple comparison).

of COX-2 compared to control group treated with LPS only. Especially, $50 \mu \mathrm{M}$ diosmin inhibited the expression of COX-2 by more than $22.5 \%$. The effect of diosmin on the expression of cytokines, including $I L-6, I L-12$, and TNF- $\alpha$, was investigated using LPS-induced RAW264.7 cells. As shown in Figures 4C, D, and E, almost undetectable expres- sions of cytokines (IL-6, IL-12, and TNF- $\alpha$, respectively) were observed in LPS-untreated RAW264.7 cells, whereas macrophages treated with LPS alone for $24 \mathrm{~h}$ significantly showed an enhanced expression of IL-6, IL-12, and TNF- $\alpha$ $(p<0.05)$. Diosmin inhibited the expression of $I L-6$ in a dose-dependent manner, but diosmin at concentration of
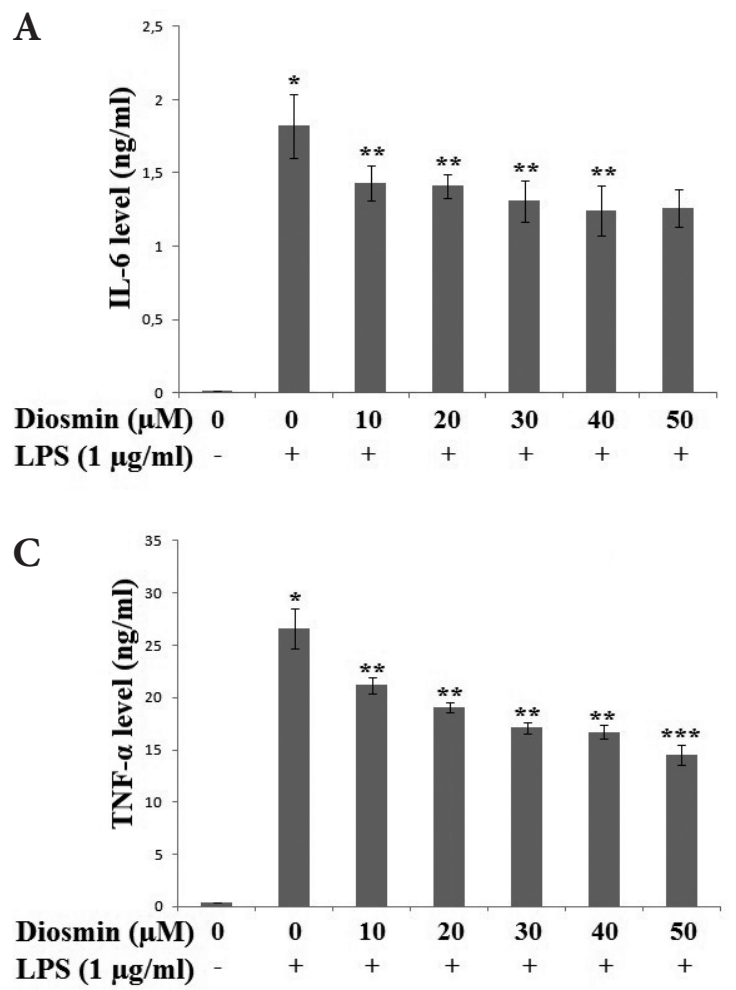

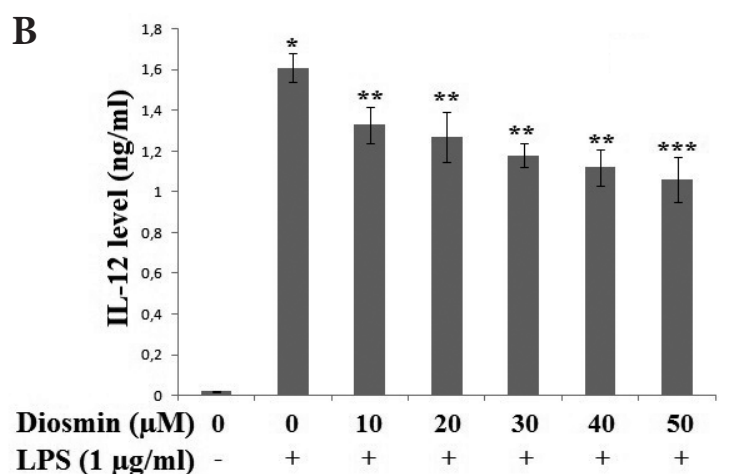

Figure 3. Inhibitory effect of diosmin on IL-6 (A), IL-12 (B), and TNF- $\alpha($ C) production in LPS-induced RAW264.7 macrophages. RAW264.7 macrophages were exposed to diosmin together with LPS $(1 \mu \mathrm{g} / \mathrm{ml})$. Level of cytokine expression in the culture media was measured using ELISA. Data represent the means \pm SD of three independent experiments. ${ }^{\star} p<0.001$ in comparison to untreated controls; significant difference was determined using unpaired Student's $t$-test; ${ }^{* *} p<0.05$ and ${ }^{* * *} p<0.001$ in comparison to cells treated with LPS alone by one-way ANOVA followed by Tukey's test for multiple comparison. 
$40 \mu \mathrm{M}$ showed the highest inhibitory effect on $I L-6$ expression ( Fig. 4C) $(p<0.05)$. Diosmin inhibited the expression of $I L-12$ and TNF- $\alpha$ in a dose-dependent manner $(p<0.05)$, and diosmin at concentration of $50 \mu \mathrm{M}$ showed the highest inhibitory effect on $I L-12$ and TNF- $\alpha$ expression (Fig. 4D and E) $(p<0.05)$.

The effect of diosmin on the activation of NF- $\kappa \mathrm{B}$ was investigated by analyzing the inhibition of I $\kappa B-\alpha$ phosphorylation in LPS-induced RAW264.7 cells. As shown in Figure 5, the activation of IкB- $\alpha$ via phosphorylation significantly increased in LPS-stimulated RAW264.7 cells, whereas di- osmin inhibited the activation of IKB- $\alpha(p<0.05)$. It was found that treatment with diosmin at $50 \mu \mathrm{M}$ significantly triggered the highest inhibitory effect on phosphorylation

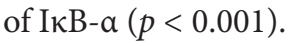

The inhibitory effects of diosmin on LPS-induced MAPKs (JNK, ERK, and p38) phosphorylation were investigated (Fig. 6). The phosphorylation levels of JNK, ERK, and p38 were increased in LPS-induced RAW264.7 macrophages, as shown in Figures 6A, B, and C, respectively. Diosmin at 40 and $50 \mu \mathrm{M}$ concentrations significantly suppressed the expression of phosphorylated-JNK compared with control
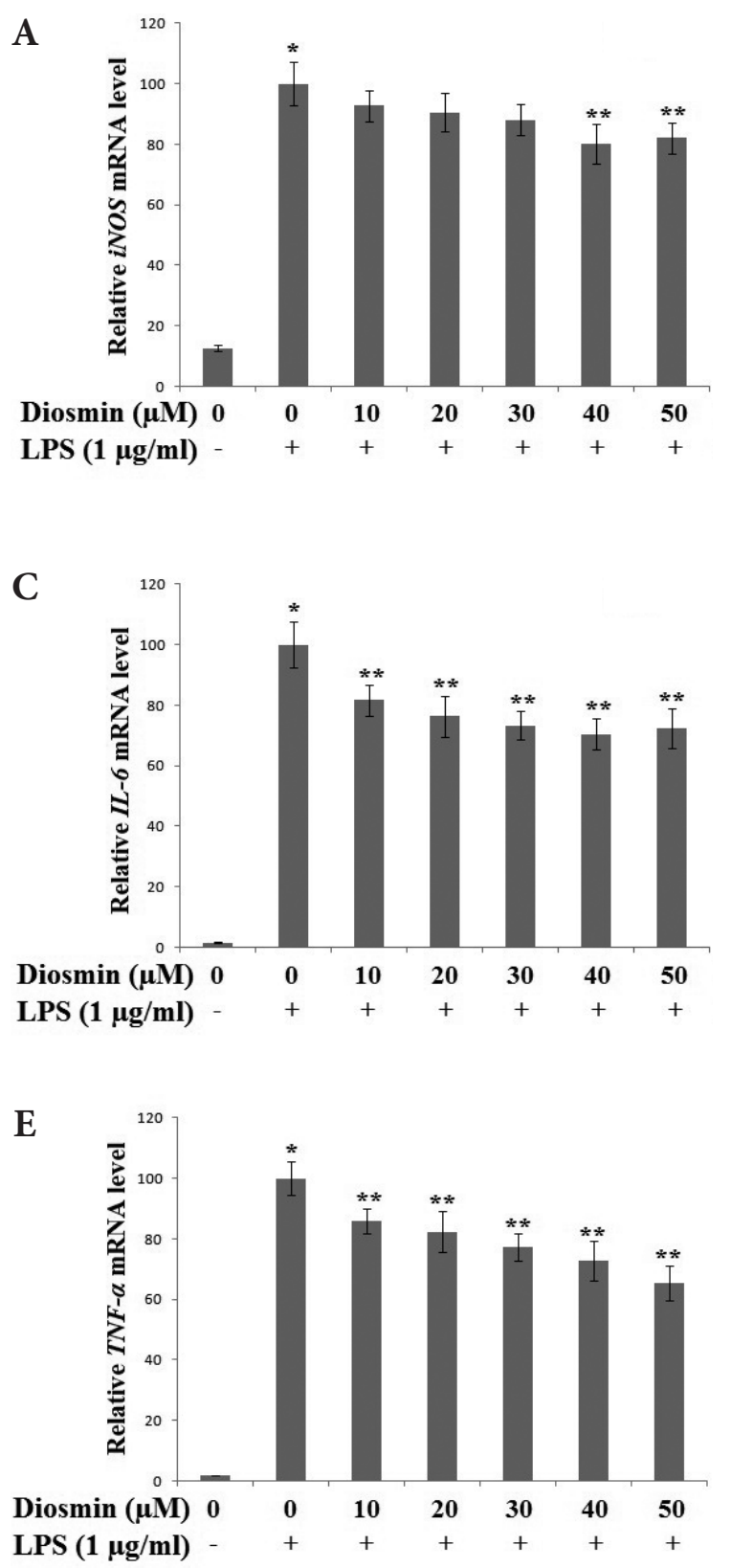
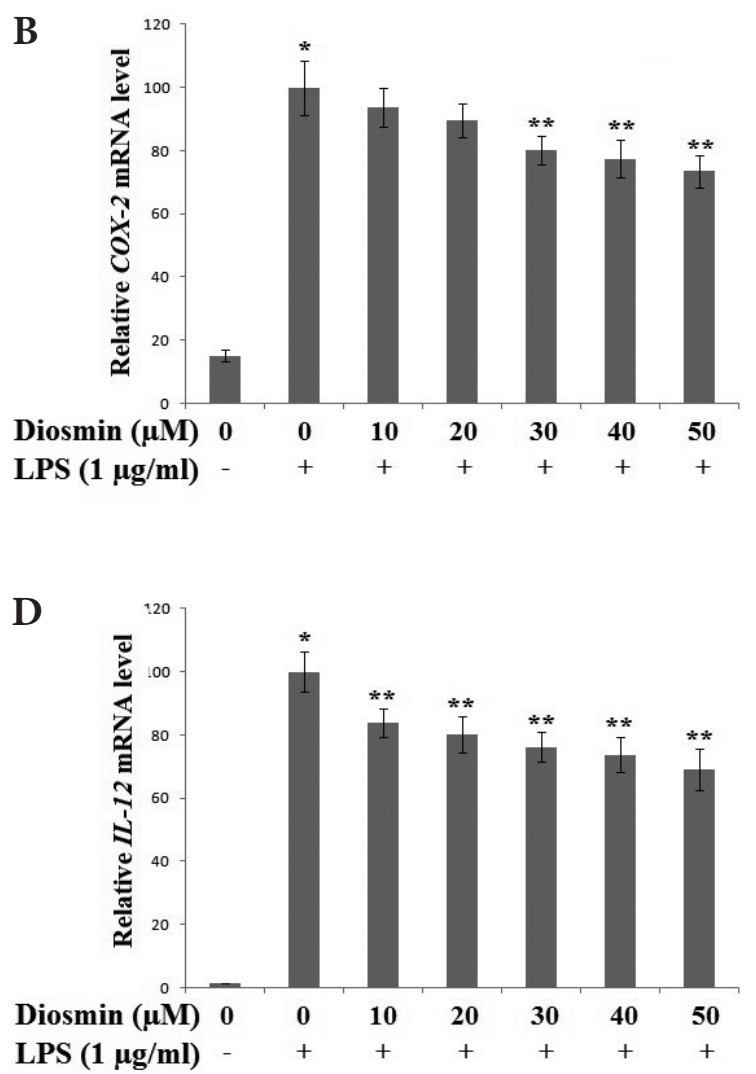

Figure 4. Inhibitory effect of diosmin on $i N O S(A), C O X-2$ (B), IL-6 (C), IL-12 (D), and TNF- $\alpha$ (E) mRNA expression in LPS-induced RAW264.7 macrophages. RAW264.7 macrophages were exposed to diosmin together with LPS $(1 \mu \mathrm{g} / \mathrm{ml})$. mRNA levels were analyzed by real-time RT-PCR. Relative mRNA levels are expressed as the percentage of intensity to the cells treated with LPS alone, which was set to $100 \%$. Data represent the means \pm SD of three independent experiments. ${ }^{\star} p<0.001$ in comparison to untreated controls; significant difference was determined using unpaired Student's $t$-test; ${ }^{* *} p<0.05$ in comparison to cells treated with LPS alone by one-way ANOVA followed by Tukey's test for multiple comparison. 


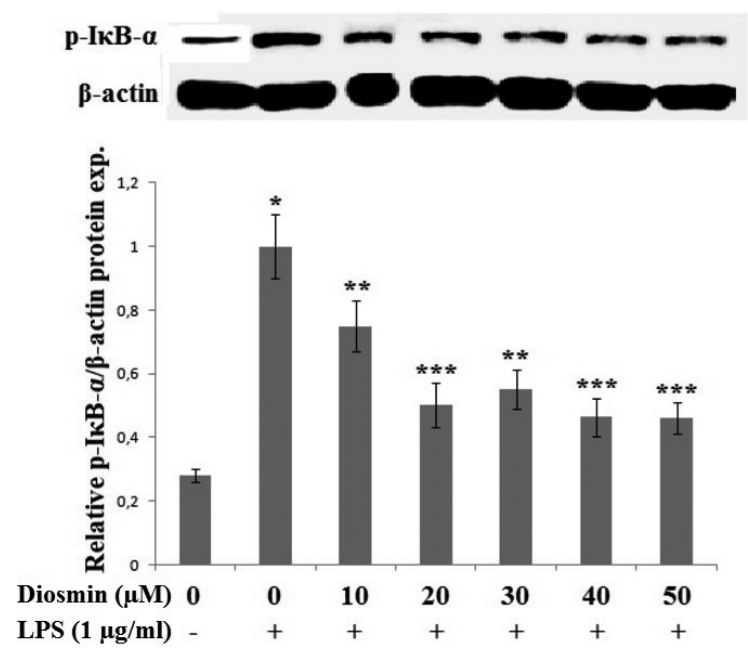

Figure 5. Effect of diosmin on phosphorylation of I $\kappa$ B- $\alpha$ in LPSstimulated RAW264.7 macrophages. RAW264.7 macrophages were incubated for $24 \mathrm{~h}$ and exposed to LPS $(1 \mu \mathrm{g} / \mathrm{ml})$ with diosmin for

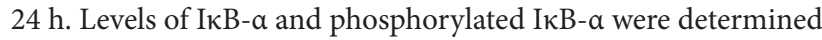
using Western blot assay. Relative protein levels are expressed as the fold of intensity to the cells treated with LPS alone, which was set to 1.00. Data represent the means \pm SD of three independent experiments. ${ }^{\star} p<0.001$ in comparison to untreated controls; significant difference was determined using unpaired Student's t-test; ${ }^{* *} p<0.05$ and ${ }^{* * *} p<0.001$ in comparison to cells treated with LPS alone by one-way ANOVA followed by Tukey's test for multiple comparison.

group treated with LPS only ( $p<0.001)$, but this suppression didn't statistically significant on the other concentrations ( $p>0.05$ ) (Fig. 6A). Moreover, diosmin significantly inhibited the expression of phosphorylated-ERK and p38 in a dose-dependent manner, in an other saying, diosmin at concentration of $50 \mu \mathrm{M}$ showed the highest suppression effect on the phosphorylation of ERK and p38 $(p<0.001)$ (Fig. 6B,C).

\section{Discussion}

Inflammation involves many complex interactions between cellular and inflammatory mediators. During the inflammatory process, significant amounts of NO and prostaglandin E2 are produced via the expression of $i N O S$ and COX-2 (Lu et al. 2017). The excessive production of proinflammatory mediators by macrophages can induce variety of inflammation-related disorders; thus, agents that suppress the production of these factors may have the potential to protect against inflammatory diseases (Jung et al. 2007; Yun et al. 2014; Song et al. 2016). We investigated the inhibitory effects of diosmin on LPS-induced proinflammatory media- tors in RAW264.7 cells. The results revealed that the inhibition of LPS-induced $\mathrm{NO}$ and $\mathrm{PGE}_{2}$ production by diosmin was accompanied by a reduction in $i N O S$ and COX-2 gene expressions, respectively. Macrophage activation induced by LPS resulted in the secretion of typical proinflammatory cytokines including IL-6, IL-12, and TNF- $\alpha$ (An et al. 2006). TNF- $\alpha$ is a key mediator in the inflammatory process and stimulates other cytokines such as IL-6 and IL-12. Additionally, the cytokines IL- 6 and IL-12 are known to upregulate the production of iNOS in macrophages (Jana et al. 2003), while IL-12 also promotes NF- $\kappa \mathrm{B}$ activation in macrophages (Pahan et al. 2001). These cytokines induce the expression of $i N O S$ and NO, and overexpression of proinflammatory mediators can result in tissue injury and multiple organ failure (Amirshahrokhi and Khalili 2016). The upregulated IL-6, IL-12, and TNF- $\alpha$ levels in LPS-induced RAW264.7 cells were significantly decreased with treatment of diosmin compared with control group treated with LPS only. 40 and $50 \mu \mathrm{M}$ diosmin were more potent inhibitor of the cytokines in this study. Diosmin at all concentrations significantly reduced the mRNA expression of $I L-6, I L-12$, and TNF- $\alpha$ compared with control group treated with LPS only. Furthermore, diosmin at concentrations of 40 and $50 \mu \mathrm{M}$ showed higher inhibitory effect on $I L-6, I L-12$, and TNF- $\alpha$ mRNA expression. We have estimated that, diosmin may inhibit posttranscriptional pathway of IL- 6 and IL-12 proteins.

LPS activates typical inflammatory signaling pathways, including the NF- $\kappa \mathrm{B}$ signaling pathway. NF- $\kappa \mathrm{B}$ is a mammalian transcription factor that regulates proinflammatory mediators and cytokines in LPS-induced macrophages and exists as a heterodimer comprising p50 and p65 subunits known to mediate the expression of genes associated with immune modulation (Gao et al. 2013). In unstimulated macrophages, NF- $\kappa B$ remains inactive in the cytoplasm bound to I $\kappa$ B- $\alpha$. The activation of NF- $\kappa$ B by LPS stimulation occurs through phosphorylation and subsequent degradation of $I \kappa B-\alpha$, followed by nuclear translocation of free NF- $\kappa B$ (Liu et al. 2002). Following activation, NF- $\kappa B$ regulates gene transcription of $i N O S, C O X-2, I L-6, I L-12$, and TNF- $\alpha$ (Kim et al. 2010). Our results show that diosmin significantly reduced LPS-induced phosphorylation of I $\kappa \mathrm{B}-\alpha$. These results demonstrate that NF- $\kappa \mathrm{B}$ activation by phosphorylation of I $\kappa \mathrm{B}-\alpha$ is suppressed by diosmin. $50 \mu \mathrm{M}$ diosmin showed the highest inhibitory effect on phosphorylation of IкB- $\alpha$.

The activation of MAPK pathways in macrophages is strongly associated with the inflammatory response and activates downstream proinflammatory cytokines and mediators. The MAPKs include ERK, p38, and JNK, and their signaling pathways play a crucial role in biological processes in addition to typical inflammatory signaling (Sui et al. 2014). MAPK signaling can be activated by LPS, which upregulates the production of NO in RAW264.7 cells (Diao et al. 2014). 
The activation of ERK in response to LPS in turn leads to the upregulation of $i N O S$ and proinflammatory cytokines (Han et al. 2013). Furthermore, LPS-induced COX-2, iNOS, and TNF- $\alpha$ expression in macrophages is regulated by $\mathrm{p} 38$ and JNK (Kim et al. 2010). In this study, the phosphorylation levels of p38 and ERK were significantly attenuated by treatment of diosmin compared with RAW264.7 cells treated with LPS only. Increased phosphorylation level of JNK was significantly reduced by 40 and $50 \mu \mathrm{M}$ diosmin treatment. These results demonstrate that diosmin is a potent inhibitor of MAPK signaling, resulting in a greater reduction of proinflammatory mediators and cytokines. Blockade of NF$\kappa \mathrm{B}$ and MAPK signaling pathways by diosmin could cause potential inhibition of LPS-induced COX-2, iNOS, NO, and cytokine production.

Some flavonoids from natural products are known to inhibit and/or reduce the progression of inflammation (Kim et al. 2004). Flavonoids appear to exhibit anti-inflammatory properties via the modulation of reactive oxygen species that induce the activation of NF- $\mathrm{KB}$ and subsequent release of cytokines (Martínez-Flórez et al. 2005). Hajimahmoodi et al. (2014) have reported that diosmin has a powerful
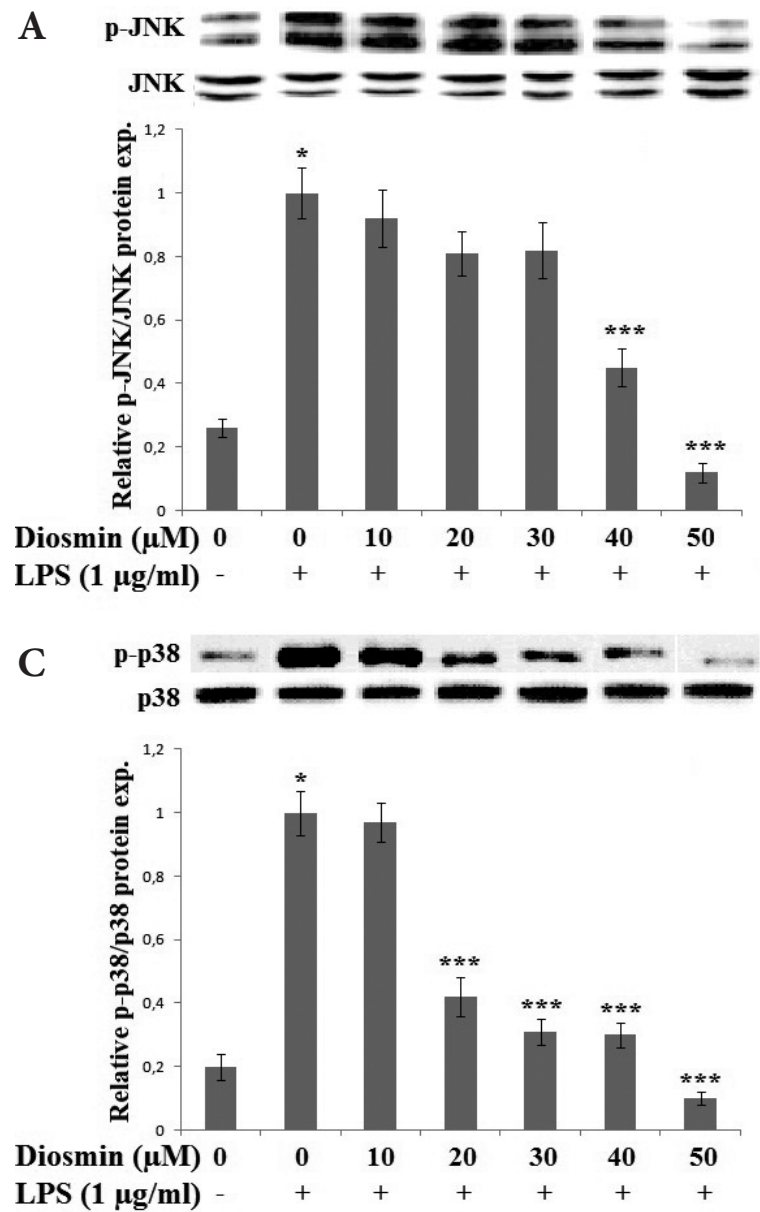

DPPH radical scavenging, reducing power, superoxide anion scavenging activity, and directly scavenging intracellular radicals. We therefore speculate that diosmin, which exhibits a potent antioxidant property, may show an antiinflammatory effect.

In conclusion, in this study, anti-inflammatory effects of diosmin was investigated in LPS-stimulated RAW264.7 macrophages. Our findings indicate that diosmin at high concentrations (40 and $50 \mu \mathrm{M}$ ) exhibits more potent inhibition of the production of proinflammatory mediators including cytokines, $\mathrm{NO}$, and $\mathrm{PGE}_{2}$ in LPS-stimulated RAW264.7 macrophages. These outcomes are mediated by the suppression of NF- $\kappa \mathrm{B}$ activation by preventing I $\kappa \mathrm{B}-\alpha$ degradation and MAPK phosphorylation in LPS-stimulated RAW264.7 macrophages. Taken together, our results suggest that diosmin is a potent anti-inflammatory agent and has potential for development into a therapeutic agent for inflammation-associated disorders.

Acknowledgement. This research was financially supported in part by the Office of Scientific Research Projects of Yuzuncu Yil University under Grant number (TAP-2018-6956).

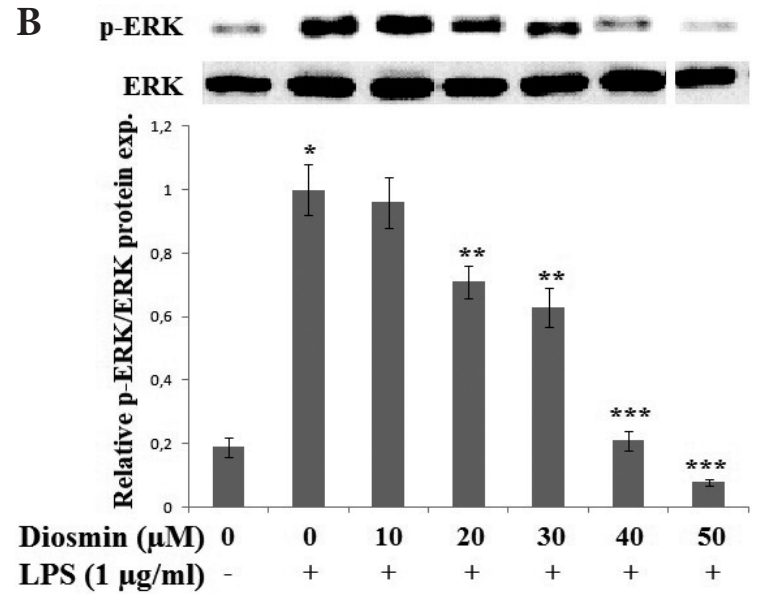

Figure 6. Effect of diosmin on phosphorylation of MAPKs; JNK (A), ERK (B), and p38 (C) in LPS-stimulated RAW264.7 macrophages. RAW264.7 macrophages were incubated for $24 \mathrm{~h}$ and exposed to diosmin with LPS $(1 \mu \mathrm{g} / \mathrm{ml})$ for $24 \mathrm{~h}$. Whole protein was determined using Western blot assay. Relative protein levels are expressed as the fold of intensity to the cells treated with LPS alone, which was set to 1.00. Data represent the means \pm SD of three independent experiments. ${ }^{*} p<0.001$ in comparison to untreated controls; significant difference was determined using unpaired Student's $t$-test; ${ }^{* *} p<0.05$ and ${ }^{* * *} p<0.001$ in comparison to cells treated with LPS alone by one-way ANOVA followed by Tukey's test for multiple comparison. 


\section{References}

Ahmed S, Mundhe N, Borgohain M, Chowdhury L, Kwatra M, Bolshette N, Ahmed A, Lahkar M (2016): Diosmin modulates the NF-kB signal transduction pathways and downregulation of various oxidative stress markers in alloxan-induced diabetic nephropathy. Inflammation 39, 1783-1797

https://doi.org/10.1007/s10753-016-0413-4

Amirshahrokhi K, Khalili AR (2016): Carvedilol attenuates paraquat-induced lung injury by inhibition of proinflammatory cytokines, chemokine MCP-1, NF- $\kappa$ B activation and oxidative stress mediators. Cytokine 88, 144-153 https://doi.org/10.1016/j.cyto.2016.09.004

An HJ, Jeong HJ, Um JY, Kim HM, Hong SH (2006): Glechoma hederacea inhibits inflammatory mediator release in IFNgamma and LPS-stimulated mouse peritoneal macrophages. J. Ethnopharmacol. 106, 418-424 https://doi.org/10.1016/j.jep.2006.01.024

Baek KS, Hong YD, Kim Y, Sung NY, Yang S, Lee KM, Park JY, Park JS, Rho HS, Shin S S, Cho JY (2015): Anti-inflammatory activity of AP-SF, a ginsenoside-enriched fraction, from Korean ginseng. J. Ginseng Res. 39, 155-161 https://doi.org/10.1016/j.jgr.2014.10.004

Baek KS, Yi YS, Son YJ, Yoo S, Sung NY, Kim Y, Hong S, Aravinthan A, Kim JH, Cho JY (2016): In vitro and in vivo anti-inflammatory activities of Korean Red Ginseng-derived components. J. Ginseng Res. 40, 437-444 https://doi.org/10.1016/j.jgr.2016.08.003

Berkoz M, Allahverdiyev O (2017): Punicalagin isolated from Punica granatum husk can decrease the inflammatory response in RAW264.7 macrophages. East. J. Med. 22, 57-64 https://doi.org/10.5505/ejm.2017.08760

Cesarone MR, Belcaro G, Pellegrini L, Ledda A, Di Renzo A, Vinciguerra G, Ricci A, Gizzi G, Ippolito E, Fano F, et al. (2005): HR, 0-(beta-hydroxyethyl)-rutosides, in comparison with diosmin+hesperidin in chronic venous insufficiency and venous microangiopathy: an independent, prospective, comparative registry study. Angiology 56, 1-8 https://doi.org/10.1177/000331970505600101

Dholakiya SL, Benzeroual KE (2011): Protective effect of diosmin on LPS-induced apoptosis in PC12 cells and inhibition of TNF-a expression. Toxicol. In Vitro 25, 1039-1044 https://doi.org/10.1016/j.tiv.2011.04.003

Diao Y, Xin Y, Zhou Y, Li N, Pan X, Qi S, Qi Z, Xu Y, Luo L, Wan H, Lan L, Yin Z (2014): Extracellular polysaccharide from Bacillus sp. strain LBP32 prevents LPS-induced inflammation in RAW 264.7 macrophages by inhibiting NF- $\kappa B$ and MAPKs activation and ROS production. Int. Immunopharmacol. 18, 12-19 https://doi.org/10.1016/j.intimp.2013.10.021

Gao M, Chen L, Yu H, Sun Q, Kou J, Yu B (2013): Diosgenin down-regulates NF- $\kappa B$ p65/p50 and p38MAPK pathways and attenuates acute lung injury induced by lipopolysaccharide in mice. Int. Immunopharmacol. 15, 240-245 https://doi.org/10.1016/j.intimp.2012.11.019

Gautam R, Jachak SM (2009): Recent developments in antiinflammatory natural products. Med. Res. Rev. 29, 767-820 https://doi.org/10.1002/med.20156
Guha M, Mackman N (2001): LPS induction of gene expression in human monocytes. Cell Signal. 13, 85-94 https://doi.org/10.1016/S0898-6568(00)00149-2

Hajimahmoodi M, Moghaddam G, Mousavi SM, Sadeghi N, Oveisi MR, Jannat B (2014): Total antioxidant activity, and hesperidin, diosmin, eriocitrin and quercetin contents of various lemon juices. Trop. J. Pharm. Res. 13, 951-956 https://doi.org/10.4314/tjpr.v13i6.18

Han S, Lee JH, Kim C, Nam D, Chung WS, Lee SG, Ahn KS, Cho SK, Cho M, Ahn KS (2013): Capillarisin inhibits iNOS, COX2 expression, and proinflammatory cytokines in LPS-induced RAW 264.7 macrophages via the suppression of ERK, JNK, and NF- $\kappa \mathrm{B}$ activation. Immunopharmacol. Immunotoxicol. $35,34-42$ https://doi.org/10.3109/08923973.2012.736522

Jana M, Dasgupta S, Saha RN, Liu X, Pahan K (2003): Induction of tumor necrosis factor-alpha (TNF-alpha) by interleukin-12 p40 monomer and homodimer in microglia and macrophages. J. Neurochem. 86, 519-528 https://doi.org/10.1046/j.1471-4159.2003.01864.x

Jung HW, Chung YS, Kim YS, Park YK (2007): Celastrol inhibits production of nitric oxide and proinflammatory cytokines through MAPK signal transduction and NF-kappaB in LPSstimulated BV-2 microglial cells. Exp. Mol. Med. 39, 715-721 https://doi.org/10.1038/emm.2007.78

Kim HP, Son KH, Chang HW, Kang SS (2004): Anti-inflammatory plant flavonoids and cellular action mechanisms. J. Pharmacol. Sci. 96, 229-245 https://doi.org/10.1254/jphs.CRJ04003X

Kim KN, Heo SJ, Yoon WJ, Kang SM, Ahn G, Yi TH, Jeon YJ (2010): Fucoxanthin inhibits the inflammatory response by suppressing the activation of NF- $\mathrm{KB}$ and MAPKs in lipopolysaccharideinduced RAW 264.7 macrophages. Eur. J. Pharmacol. 649, 369-375

https://doi.org/10.1016/j.ejphar.2010.09.032

Lee SY, Kim HJ, Han JS (2013): Anti-inflammatory Effect of Oyster Shell Extract in LPS-stimulated Raw 264.7 Cells. Prev. Nutr. Food Sci. 18, 23-29 https://doi.org/10.3746/pnf.2013.18.1.023

Lee HM, Kim TS, Jo EK (2016): miR-146 and miR-125 in the regulation of innate immunity and inflammation. BMB Rep. 49, 311-318 https://doi.org/10.5483/BMBRep.2016.49.6.056

Liu F, Morris S, Epps J, Carroll R (2002): Demonstration of an activation regulated NF-kappaB/I-kappaBalpha complex in human platelets. Thromb. Res. 106, 199-203 https://doi.org/10.1016/S0049-3848(02)00130-5

Lu X, Min L, Wei J, Gou H, Bao Z, Wang J, Wang Z, Huang Y, An B (2017): Heliangin inhibited lipopolysaccharide-induced inflammation through signaling NF- $\kappa B$ pathway on LPS-induced RAW 264.7 cells. Biomed. Pharmacother. 88, 102-108 https://doi.org/10.1016/j.biopha.2017.01.041

Martínez-Flórez S, Gutiérrez-Fernández B, Sánchez-Campos S, González-Gallego J, Tunón MJ (2005): Quercetin attenuates nuclear factor-kappaB activation and nitric oxide production in interleukin-1beta-activated rat hepatocytes. J. Nutr. 135, 1359-1365 https://doi.org/10.1093/jn/135.6.1359 
Melin AM, Perromat A, Clerc M (1996): In vivo effect of diosmin on carrageenan and CCl4-induced lipid peroxidation in rat liver microsomes. J. Biochem. Toxicol. 11, 27-32 https://doi.org/10.1002/(SICI)1522-7146(1996)11:1<27::AID-JBT4>3.0.CO;2-X

Meng LZ, Lin BQ, Wang B, Feng K, Hu DJ, Wang LY, Cheong KL, Zhao J, Li SP (2013): Mycelia extracts of fungal strains isolated from Cordyceps sinensis differently enhance the function of RAW 264.7 macrophages. J. Ethnopharmacol. 148, 818-825 https://doi.org/10.1016/j.jep.2013.05.017

Nowarski R, Gagliani N, Huber S, Flavell RA (2013): Innate immune cells in inflammation and cancer. Cancer Immunol. Res. 1, 77-84 https://doi.org/10.1158/2326-6066.CIR-13-0081

Pahan K, Sheikh FG, Liu X, Hilger S, McKinney M, Petro TM (2001): Induction of nitric-oxide synthase and activation of NF-kappaB by interleukin-12 p40 in microglial cells. J. Biol. Chem. 276, 7899-7905 https://doi.org/10.1074/jbc.M008262200

Queenthy SS, John B (2013): Diosmin exhibits anti-hyperlipidemic effects in isoproterenol induced myocardial infarcted rats. Eur. J. Pharmacol. 718, 213-218 https://doi.org/10.1016/j.ejphar.2013.08.031

Rajapakse N, Kim MM, Mendis E, Kim SK (2008): Inhibition of inducible nitric oxide synthase and cyclooxygenase- 2 in lipopolysaccharide-stimulated RAW264.7 cells by carboxybutyrylated glucosamine takes place via down-regulation of mitogen-activated protein kinase-mediated nuclear factorkappaB signaling. Immunology 123, 348-357 https://doi.org/10.1111/j.1365-2567.2007.02683.x

Rajasekar M, Suresh K, Sivakumar K (2016): Diosmin induce apoptosis through modulation of STAT-3 signaling in 7,12 dimethylbenz(a)anthracene induced harmster buccal pouch carcinogenesis. Biomed. Pharmacother. 83, 1064-1070 https://doi.org/10.1016/j.biopha.2016.08.019

Ren K, Jin C, Ma P, Ren Q, Jia Z, Zhu D (2016): Ginsenoside Rd alleviates mouse acute renal ischemia/reperfusion injury by modulating macrophage phenotype. J. Ginseng Res. 40, 196-202 https://doi.org/10.1016/j.jgr.2015.12.003
Saito S, Matsuura M, Hirai Y (2006): Regulation of lipopolysaccharide-induced interleukin-12 production by activation of repressor element GA-12 through hyperactivation of the ERK pathway. Clin. Vaccine Immunol. 13, 876-883 https://doi.org/10.1128/CVI.00075-06

Song SM, Ham YM, Ko YJ, Ko EY, Oh DJ, Kim CS, Kim D, Kim KN, Yoon WJ (2016): Anti-inflammatory activities of the products of supercritical fluid extraction from Litsea japonica fruit in RAW 264.7 cells. J. Funct. Foods 22, 44-51 https://doi.org/10.1016/j.jff.2016.01.008

Sui X, Kong N, Ye L, Han W, Zhou J, Zhang Q, He C, Pan H (2014): p38 and JNK MAPK pathways control the balance of apoptosis and autophagy in response to chemotherapeutic agents. Cancer Lett. 344, 174-179 https://doi.org/10.1016/j.canlet.2013.11.019

Tahir M, Rehman MU, Lateef A, Khan R, Khan AQ, Qamar W, Ali F, O'Hamiza O, Sultana S (2013): Diosmin protects against ethanolinduced hepatic injury via alleviation of inflammation and regulation of TNF- $\alpha$ and NF- $\kappa$ B activation. Alcohol 47, 131-139 https://doi.org/10.1016/j.alcohol.2012.12.010

Yi YS, Cho JY, Kim D (2016): Cerbera manghas methanol extract exerts anti-inflammatory activity by targeting c-Jun $\mathrm{N}$-terminal kinase in the AP-1 pathway. J. Ethnopharmacol. 193, 387-396 https://doi.org/10.1016/j.jep.2016.08.033

Yun JM, Im SB, Roh MK, Park SH, Kwon HA, Lee JY, Choi HY, Ham IH, Kim YB, Lee J M, et al. (2014): Prunus yedoensis bark inhibits lipopolysaccharide-induced inflammatory cytokine synthesis by IKB $\alpha$ degradation and MAPK activation in macrophages. J. Med. Food 17, 407-413 https://doi.org/10.1089/jmf.2013.2825

Zhu T, Liu TJ, Shi YY, Zhao Q (2015): Vitamin D/VDR signaling pathway ameliorates 2,4,6-trinitrobenzene sulfonic acidinduced colitis by inhibiting intestinal epithelial apoptosis. Int. J. Mol. Med. 35, 1213-1218 https://doi.org/10.3892/ijmm.2015.2150

Received: October 18, 2018

Final version accepted: March 15, 2019

First published online: June 26, 2019 